\section{PENELITIAN \\ PEMANFAATAN KULIT SAPI MENTAH DARI \\ NUSA TENGGARA BARAT UNTUK KULTT BOKS}

Suliestiyah. Wrd; Kamidjo *)
Widari **)

ABSTRACT

The aim of this study was to identify of the quality upper leather made from dry cow hide taken from West Nusa Tenggara either of leather produced before or after being provided a technical assistance, were compared to them taken from Java. It was carried out by tanning both kinds of hides using selected IRDLAI tanning method. The upper leathers produced in this research were physically tested (water absorption, tensile strength, flexibility and bursting strength), chemically tested (water content, ash content, $\mathrm{Cr}_{2} \mathrm{O}_{3}$ content, fat content and $\mathrm{pH}$ ), as well as organoleptic inspection. The physical and chemical tests were six time repeated. A consclusion could be drawn from the organoleptic test result that the quality of Java upper leather were better compared to them of West Nusa Tenggara either before or after having technical assistance, while the quality of upper leathers after having technical guidance by IRDLAI were considered better compared to them before having it. The test result also shown that there was significant difference on fat, water and ash contents, bursting strength of upper leathers, the dry cow hides of which were taken from West Nusa Tenggara, either before or after having technical assistance.

*) Balai Pengembangan Barang Kulit

**) Balai Penelitian Barang Kulit

\section{INTISARI}

Penelitian ini bertujuan untuk mengetahui mutu kulit boks dengan bahan baku kulit sapi mentah kering dari Nusa Tenggara Barat, baik sebelum maupun sesudah pembinaan dibandingkan dengan mutu kulit boks dengan bahan baku kulit sapi mentah kering dari pulau Jawa. Penelitian dilaksanakan dengan mengolah kulit mentah kering dari Nusa Tenggara Barat sebelum pembinaan dan sesudah pembinaan dan kulit mentah kering dari pulau Jawa menjadi kulit boks dengan metoda penyamakan kulit dari BBKKP. Dari hasil penyamakan kulit boks, kemudian masing-masing diuji sifat-sifat fisis (daya serap air, kekuatan tarik, kemuluran dan daya letup) dengan 6 replikasi (ulangan); sifat-sifat kimia (kadar air, kadar abu, kadar $\mathrm{Cr}_{2} \mathrm{O}_{3}$, kadar lemak dan $\mathrm{pH}$ ) dengan replikasi serta diuji secara organoleptis. Dari hasil uji secara organoleptis ternyata kulit boks asal dari Pulau Jawa lebih

Majalah Barang Kulit, Karet dan Plastik baik dibanding dengan kualitas kulit boks asal dari Nusa Tenggara Barat bulit boks baik sebelum maupun sembinaan lebih baik dibanding asal dari kulit Nusa Tenggara sesudah pembinaan lebih baik dibanding kualitas kulit boks asa! kulit dari Nusa Tenggara Barat sebelum pembinaan. Dari hasil penelitian menunjukkan terdapat perbedaan nyata untuk kadar lemak, kadar air, kadar abu, daya letup kulit boks yang berasal dari kulit Nusa Tenggara Barat, sebelum dan sesudah pembinaan.

\section{PENDAHULUAN}

Kulit sapi telah diketahui banyak manfaatnya. Untuk dapat dimanfaat kan, kulit tersebut harus mengalami proses tertentu yaitu proses penyamakan kulit. Proses penyamakan kulit adalah proses yang mengubah kulit mentah menjadi kulit tersamak, misalnya menjadi kulit boks ialah kulit jadi yang berasal dari kulit sapi atau anak sapi yang disamak dengan proses samak khrom dan umumnya digunakan untuk kulit sepatu bagian atas (upper leather). Faktor yang mempengaruhi hasil kulit jadi antara lain kualitas dari kulit mentah itu sendiri. Kualitas kulit mentah ditentukan adanya cacat-cacat yang terdapat pada kulit, baik cacat yang terjadi karena akibat dari suatu penyakit maupun cacat yang terjadi pada waktu proses pengulitan maupun pada waktu pemeliharaan hewan. Proses penyamakan yang tidak baik juga akan mempengaruhi hasil kulit jadinya.

Menurut Balai Penelitian Kulit (Anonimus, 1972) dikatakan bahwa proses pengulitan maupun pada waktu pemeliharaan hewan; proses penyamakan yang tidak baik juga akan mempengaruhi hasil kulit jadinya.

Menurut Balai Penelitian Kulit (Anonimus, 1972) dikatakan bahwa proses penyamakan kulit melalui tahap-tahap : perendaman, pengapuran, buang kapur, bating, pengasaman, penyamakan khrom, penetralan, fatliquiring, pengetaman, pengeringan, peregangan dan perentangan. Dalam proses penyamakan kulit, bagian kulit yang disamak adalah bagian kulit jangat. Kulit boks adalah kulit atasan yang dibuat dari kulit sapi yang disamak khrom, digemuk dan diberi warna hitam, coklat atau warna lainnya, digunakan untuk pembuatan sepatu biasa atau sepatu kerja. Tebal kulit boks antara : 1,6 - 2,2 $\mathrm{mm}$ atau menurut keperluan. Sifat kulit boks yang baik ialah lemas, pegangan penuh, struktur kuat, nerf tidak lepas dan tidak mudah pecah, gambar dari nerf harus kelihatan, tidak boleh tertutup oleh cat tutup.

Menurut I Mann (1960) dikatakan bahwa untuk pembuatan kulit boks diperlukan kulit mentah yang memenuhi syarat : kulit mentah berasal dari kulit sapi klas intermediate yang beratnya maksimum $5 \mathrm{~kg}$ (berat kulit kering). Kulit boks biasanya digunakan untuk pembuatan sepatu, sehingga memerlukan nerf yang baik dan tensile strength tinggi.

Nusa Tenggara Barat merupakan salah satu daerah potensial dalam

VOL VIII No. 14 Tahun 1992/1993 
penyediaan kulit mentah sapi. Oleh karena dalam rangka memanfaatkan kulit sapi dari Nusa Tenggara Barat perlu diadakan penelitian mengenai mutu kulit boks dengan bahan baku kulit sapi mentah kering dari daerah Nusa Tenggara Barat.

Tujuan penelitian ini adalah untuk mengetahui mutu kulit boks dengan bahan baku kulit sapi mentah kering dari Nusa Tenggara Barat, baik sebelum maupun sesudah diadakan pembinaan mengenai cara-cara pengulitan serta pengawetan kulit mentah, dibandingkan dengan mutu kulit boks dengan bahan baku kulit sapi mentah kering dari Pulau Jawa.

\section{MATERI DAN METODA PENELITIAN}

\section{MATERI PENELITIAN}

a. Kulit

Kulit yang digunakan dalam penelitian ini adalah kulit sapi mentah kering yang diambil dari Propinsi Nusa Tenggara Barat dan Pulau Jawa, sejumlah 36 lembar dengan perincian sebagai berikut : 12 lembar contoh dari Nusa Tenggara Barat sebelum pembinaan : $12 \mathrm{lem}$ bar contoh kulit sapi mentah kering yang diambil dari Nusa Tenggara Barat setelah diadakan pembinaan dan 12 lembar contoh kulit sapi mentah kering yang berasal dari Pulau Jawa.

b. Bahan Penyamak yang digunakan dalam penelitian ini adalah bahan penyamak khrom.

c. Bahan kimia dan bahan-bahan lainnya yang digunakan dalam penelitian ini adalah : obat pembasah, obat pencegah bakteri, obat bating, minyak sulfat, $\mathrm{NaCl}$; $\mathrm{Na} 2 \mathrm{~S} ; \mathrm{Ca}(\mathrm{OH}) 2$; (NH4)2SO4; $\mathrm{Na} 2 \mathrm{CO} 3$; $\mathrm{Na} 2 \mathrm{HCO} 3$ dan bahan penyamak syntetik. Untuk pengujian/analisa kulit secara kimiawi digunakan bahan-bahan kimia antara lain : Xylol; $\mathrm{HO}_{2} \mathrm{SO} 4$; aquadest; $\mathrm{CCl} 4 ; \mathrm{HCl}$ dan lain sebagainya.

d. Mesin dan peralatan

Dalam proses penyamakan digunakan alat-alat dan mesin sebagai berikut : bak perendam, bak pengapuran, mesin buang daging, mesin pembelah, mesin peregang, drum penyamakan, dan papan pentangan. Selain itu juga digunakan alat-alat seperti : pisau, kompor, panci, paku, tong, kertas $\mathrm{pH}$, ember plastik, mangkok plastik dan lain-lain. Untuk pengujian fisis digunakan alat-alat antara lain : alat pengukur tebal, timbangan, pesawat KUBELKA, pesawat uji ketahanan tarik dan lain sebagainya. Sedangkan untuk uji kimiawi digunakan alat : krus porselin, labu Erlenmeyer, gelas piala dan lain sebagainya.

\section{METODA PENELITIAN}

2.1. Proses penyamakan kulit

Proses penyamakan kulit sapi mentah kering dari Nusa Tenggara 28

Majalah Barang Kulit, Karet dan Plastik

Barat sebelum diadakan pembinaan. Untuk tiap proses digunakan 4 lembar kulit sapi yang diambil secara acak dilakukan 3 kali ulangan. Kemudian kulit di proses menjadi kulit boks. Pelaksanaan proses penyamakan kulit menjadi kulit boks sebagai berikut :

a. Perendaman (soaking)

Maksud perendaman ini ialah untuk mengembalikan sifat-sifat kulit mentah seperti keadaan semula, lemas, lunak dsb. Kulit mentah kering setelah ditimbang kemudian direndam dalam larutan :

- $1 \mathrm{~g} / \mathrm{l}$ Depan B

- Antimould $1 / 2 \mathrm{~g} / 1$

- $1000 \%$ air

Direndam selama 24 jam. Keesokan hari kulit diangkat dan diputar dalam drum selama 30 menit. Kemudian diputar lagi dengan air secukupnya selama 15 menit. Kulit diangkat dan digantung kemudian ditimbang.

b. Pengapuran (liming)

Setelah perendaman meningkat pada Proses pengapuran. Kulit direndam dalam larutan : $7 \% \mathrm{Na} 2 \mathrm{~S} ; 10 \% \mathrm{Ca}(\mathrm{OH}) 2 ; 400 \%$ air (semua dihitung dari berat kulit setelah perendaman). Diputar dalam drum selama 2 jam, setelah itu direndam selama 24 jam. Kulit setelah direndam, diangkat dan dicuci. Kulit dibuang dagingnya dengan mesin pembuang daging, serta dikerok untuk membuang bulu kasar dan bulu halusnya kemudian dicuci bersih.

c. Pembelahan (spilitting)

Kulit ditipiskan menurut tebal yang dikehendaki dengan jalan membelah kulit tersebut menjadi lembaran kulit, ini dikerjakan dengan mesin pembelah.

d. Pembuang kapur (deliming) dan bating

Kulit dicuci dalam drum dalam larutan air selama 30 menit, guna menghilangkan kapur yang tak terikat, kemudian diputar dengan : 1,5\% ZA; $200 \%$ air selama 15 menit. Setelah diputar selama 1 jam diperiksa dengan phenol pthalein indikator warna putih pada penampang potongan kulit, kemudian dicuci bersih.

e. Pengasaman (pickling)

$10 \%$ garam dapur; $0,5 \mathrm{HCOOH} ; 1,5 \% \mathrm{H} 2 \mathrm{SO} 4 ; 80 \%$ air. Garam dapur dilarutkan terlebih dahulu dengan air, dimasukkan dalam drum, kemudian diputar selama 15 menit, ditambah $\mathrm{HCOOH}$ secara perlahan-lahan, dimasukkan tiga kali, diputar 15 menit untuk setiap kali memasukkan $\mathrm{HCOOH}$. Ditambah lagi $\mathrm{H}_{2} \mathrm{SO} 4$ perlahan-lahan, diputar terus selama $1 \mathrm{jam}$. Kemudian diperiksa sampai mencapai pH 3 - 3,5 dan seluruh penampang kuning terhadap brome cresol green indikator.

VOL VIII No. 14 Tahun 1992/1993 


\section{f. Penyamakan (Tanning)}

Kesokan harinya proses dilanjutkan dengan penyamakan. $10 \%$ chromoduol; $80 \%$ air pickel bekas; $1,5 \mathrm{NaHCO}$. Chromodual dimasukkan dalam air pickel, diputar lagi dalam selama 2 jam, kemudian diperiksa pH: 5. Kulit kemudian diuji kemasakannya dengan cara direbus pada air mendidih selama lebih kurang 10 menit. Kulit dianggap masak apabila setelah direbus kulit tidak mengkerut lebih dari $10 \%$ dan tetap lemas. Kulit dikeluarkan dari drum digantungkan pada kuda-kuda. Keesokan harinya kulit diperah dengan mesin untuk menghilangkan sebagian besar airnya, kemudian kulit diketam dengan mesin ketam pada bagian dagingnya guna mengatur tebal kulit dengan merata. Kulit ditimbang guna menentukan jumlah obat yang akan digunakan untuk proses selanjutnya. Kemudian dicuci dengan air mengalir selama lebih kurang 30 menit.

\section{g. Retaning}

Kulit diputar selama lebih kurang 30 menit dengan larutan : $3 \%$ Chromodual; 60 derajat Celcius air hangat.

\section{h. Penetralan}

Cara mengerjakan : Kulit diputar dengan: $1 \%$ basyntan; $0,5 \%$ $\mathrm{NaHCO} 3$; diputar selama lebih kurang 30 menit kemudian dicuci bersih.

\section{i. Pengecatan dasar}

Kulit setelah dinetralisir diputar dengan: $0,5 \%$ derma black/sandopan shwart; $100 \mathrm{~g} / 1$ recalcin black. Sandopan Shwart/derma black dilarutkan dengan air panas 60 derajat $\mathrm{C}$ dan diputar selama lebih kurang 15 menit, kemudian ditambahkan: $0,25 \%$ glufat; $0,3 \%$ pularasol; $0,1 \%$ estrol $20 ; 1 \%$ seabophyl 10 ; diputar selama 15 menit kemudian ditambah lagi: $1,5 \%$ basyntan: $0,5 \%$ retan $\mathrm{Hp} ; 0,2 \%$ mimosa. Kulit diputar dalam drum selama lebih kurang 45 menit ditambah dengan $0,3 \% \mathrm{HCOOH}$ dan diputar selama lebih kurang 15 menit. Kulit kemudian diangkat dari drum kemudian digantungkan pada kuda-kuda. Keesokan hari kulit dipentang sampai 3 - 4 hari lamanya. Apabila telah cukup kering, kulit dilepas dari pentangan, diguntingi tepinya sampai lubang-lubang dan keriputnya hilang.

\section{Penyelesaian (finishing)}

Pengecatan Tutup.

20 liter air hangat ; $100 \mathrm{~g} / \mathrm{l}$ recalsin black; $100 \mathrm{~g} / \mathrm{l}$ recalsin brown $\mathrm{KW} 15,100 \mathrm{~g} / \mathrm{l}$ recalsin brown IMP; $100 \mathrm{~g} / \mathrm{l}$ recalsin brown PNE dan 0,5 Wox top. Kulit diulas dengan larutan cat tutup sebanyak 3 kali kemudian dijemur sampai kering. Kulit dikilapkan dengan seterika.
Kulit yang telah dicat tutup, disemprot dengan larutan pengkilap 1 . 2 kali agar pigment cat lebih terbungkus dan kulit menjadi lebih mengkilap.

Larutan pengkilap tutup:

$200 \mathrm{~g} / \mathrm{LE}$ 443; $200 \mathrm{~g} / \mathrm{LLE} 217 ; 300 \mathrm{~g} / \mathrm{l}$ super tinner. Kulit kemudian dijemur sampai kering, dilanjutkan dengan seterika kembali kemudian diukur luasnya.

2.2 Pelaksanaan pengujian

Hasil dari proses percobaan penelitian tersebut diuji secara organoleptis, fisis dan kimiawi menurut SII.

\subsection{Analisa Data}

Untuk mengetahui mutu kulit boks bahan baku kulit sapi dari Nusa Tenggara Barat sebelum diadakan pembinaan maupun sesudah dilakukan pembinaan dibandingkan dengan mutu kulit boks dengan bahan kulit dari P. Jawa, dilakukan pengujian statistik dengan cara CRD.

\section{HASIL PENELITIAN DAN PEMBAHASAN}

1. Pengukuran kulit mentah

Tabel 1. Rata-rata Hasil pengukuran kulit

\begin{tabular}{|c|l|c|c|}
\hline No. & $\begin{array}{c}\text { Tempat pengambilan } \\
\text { Sampel }\end{array}$ & $\begin{array}{c}\text { Luas kulit } \\
\text { (feet) }\end{array}$ & $\begin{array}{c}\text { Tebal kulit } \\
\text { (mm) }\end{array}$ \\
\hline 1. & Pulau Jawa & 13,50 & 1,75 \\
2. & $\begin{array}{l}\text { Nusa Tenggara Barat } \\
\text { (Sebelum Pembinaan) }\end{array}$ & 10,75 & 1,56 \\
3. & $\begin{array}{l}\text { Nusa Tenggara Barat } \\
\text { (Sesudah Pembinaan) }\end{array}$ & 13,50 & 1,57 \\
\hline
\end{tabular}

VOL VIII No. 14 Tahun 1992/1993 


\section{Pengujian secara Organoleptis}

Tabel 2 : Hasil Pengujian organoleptis Kulit mentah

\begin{tabular}{|l|l|c|c|c|c|c|}
\hline \multirow{2}{*}{ No. } & Tempat pengambilan & \multicolumn{5}{|c|}{ Kualitas (\%) } \\
\cline { 3 - 7 } & Sampel kulit mentah. & I & II & III & IV & R \\
\hline 1. & Pulau Jawa & 16,67 & 25,00 & 58,33 & - & - \\
2. & $\begin{array}{l}\text { Nusa Tenggara Barat } \\
\text { (Sebelum Pembinaan) }\end{array}$ & - & - & 16,70 & 50,00 & 35,30 \\
3. & $\begin{array}{l}\text { Nusa Tenggara Barat } \\
\text { (Sesudah Pembinaan) }\end{array}$ & - & 16,67 & 50,00 & 33,33 & - \\
\hline
\end{tabular}

Tabel 3 : Hasil pengujian organoleptis kulit Boks

\begin{tabular}{|c|l|c|c|c|c|c|}
\hline \multirow{2}{*}{ No. } & Tempat pengambilan & \multicolumn{5}{|c|}{ Kualitas (\%) } \\
\cline { 3 - 7 } & Sampel kulit mentah. & I & II & III & IV & R \\
\hline 1. & Pulau Jawa & 12.50 & 33,33 & 54,17 & - & - \\
2. & $\begin{array}{l}\text { Nusa Tenggara Barat } \\
\text { (Sebelum Pembinaan) }\end{array}$ & - & - & 58,33 & 12,5 & 29,17 \\
3. & $\begin{array}{l}\text { Nusa Tenggara Barat } \\
\text { (Sesudah Pembinaan) }\end{array}$ & - & - & 70,83 & 25,00 & 4,17 \\
\hline
\end{tabular}

2. Pengujian fisika dan kimia untuk kulit boks

2.1. Kadar lemak

Tabel 4 : Kadar lemak kulit boks hasil proses penyamakan dariJawa, N.T.B. sebelum dan sesudah pembinaan (\%)

\begin{tabular}{|c|c|c|c|}
\hline No. & Jawa & $\begin{array}{c}\text { N.T.B. sebelum } \\
\text { pembinaan }\end{array}$ & $\begin{array}{c}\text { N.T.B. sesudah } \\
\text { pembinaan }\end{array}$ \\
\hline 1. & 4,937 & 2,815 & 4,370 \\
2. & 5,158 & 3,405 & 4,750 \\
3. & 4,927 & 3,380 & 4,110 \\
4. & 4,609 & 2,895 & 4,000 \\
5. & 5,234 & 3,240 & 4,180 \\
6. & 4,132 & 2,920 & 5,070 \\
\hline
\end{tabular}

Tabel 5 : Analisa variasi kadar lemak kulit boks hasil proses penyamakan kulit dari P. Jawa, Nusa Tenggara Barat sebelum dan sesudah pembinaan.

\begin{tabular}{|l|c|c|c|c|}
\hline Sumber variasi & df & SS & MS & F \\
\hline Perlakuan & 2 & 9,73 & 4,87 & \\
Error & 15 & 2,00 & 0,13 & 37,46 \\
\hline
\end{tabular}

Test Duncan's

\begin{tabular}{lll} 
& 2 & 3 \\
\hline SSR & 3,01 & 3,16 \\
\hline LSD & 0,45 & 0,47 \\
\hline B & C & A
\end{tabular}

Hasil uji kadar lemak kulit boks seperti terlihat pada Tabel 4, dan analisa variasinya yang tercantum pada tabel 5 , ternyata kadar lemak kulit boks dengan bahan baku kulit dari P. Jawa dan dari Nusa Tenggara Barat sesudah diadakan pembinaan, tidak terdapat perbedaan yang nyata $(P \leq 0,05)$, tetapi berbeda sangat nyata dengan kadar lemak kulit boks dengan bahan baku kulit dari Nusa Tenggara Barat sebelum diadakan pembinaan. $(P \geq 0,01)$

2.2. Kadar air

Tabel 6: Kadar air kulit boks hasil proses penyamakan kulit dari P. Jawa, Nusa Tenggara Barat sebelum dan sesudah pembinaan (\%).

\begin{tabular}{|c|c|c|c|}
\hline No. & Jawa & $\begin{array}{c}\text { N.T.B. sebelum } \\
\text { pembinaan }\end{array}$ & $\begin{array}{c}\text { N.T.B. sesudah } \\
\text { pembinaan }\end{array}$ \\
\hline 1. & 18,488 & 22,482 & 20,000 \\
2. & 19,245 & 21,244 & 20,000 \\
3. & 18,991 & 21,240 & 20,990 \\
4. & 19,741 & 21,334 & 18,990 \\
5. & 19,239 & 21,280 & 19,990 \\
6. & 19,976 & 21,475 & 19,980 \\
\hline
\end{tabular}


Tabel 7 : Analisa variasi kadar air kulit boks hasil proses penyamakan kulit dari Jawa, NTB sebelum dan sesudah pembinaan.

\begin{tabular}{|l|c|c|c|c|}
\hline Sumber variasi & df & SS & MS & F \\
\hline Perlakuan & 2 & 16,27 & 8,14 & \\
Error & 15 & 4,31 & 0,29 & $28,07^{* *}$ \\
\hline
\end{tabular}

Test Duncan's

\begin{tabular}{lll} 
& 2 & 3 \\
\hline SSR & 3,01 & 3,16 \\
\hline LSD & 0,66 & 0,69 \\
\hline A & C & B
\end{tabular}

Hasil uji kadar air kulit boks seperti terlihat pada tabel 6 dan analisa variasinya pada tabel 7, dapat diketahui bahwa kadar air kulit boks dengan bahan baku kulit di P. Jawa, dari Nusa Tenggara Barat sebelum pembinaan dan dari Nusa Tenggara Barat sesudah diadakan pembinaan terdapat perbedaan yang sangat nyata. $(P \leq 0,01)$

\subsection{Kadar Abu}

Tabel 8 : Kadar abu kulit boks hasil proses penyamakan kulit dari Jawa, Nusa Tenggara Barat sebelum dan sesudah pembinaan (\%).

\begin{tabular}{|c|c|c|c|}
\hline No. & Jawa & $\begin{array}{c}\text { N.T.B. sebelum } \\
\text { pembinaan }\end{array}$ & $\begin{array}{c}\text { N.T.B. sesudah } \\
\text { pembinaan }\end{array}$ \\
\hline 1. & 4,508 & 4,030 & 4,670 \\
2. & 4,217 & 4,100 & 4,440 \\
3. & 3,995 & 4,185 & 5,055 \\
4. & 3,884 & 4,025 & 4,660 \\
5. & 3,504 & 4,100 & 4,550 \\
6. & 3,861 & 4,145 & 4,670 \\
\hline
\end{tabular}

Tabel 9 : Analisa variasi kadar abu kulit boks hasil proses penyamakan kulit dari P. Jawa, Nusa Tenggara Barat sebelum dan sesudah pembinaan.

\begin{tabular}{|l|r|c|c|c|}
\hline Sumber variasi & df & SS & MS & F \\
\hline Perlakuan & 2 & 1,64 & 0,82 & \\
Error & 15 & 0,81 & 0,05 & $16,4^{* *}$ \\
\hline
\end{tabular}

Test Duncan's

\begin{tabular}{lll} 
& 2 & 3 \\
\hline SSR & 3,01 & 3,16 \\
\hline LSD & 0,27 & 0,28 \\
\hline A & B & C
\end{tabular}

Hasil ui kadar abu kulit boks dan analisa variasinya seperti terliha pada tabel 8 dan tabel 9, ternyata kadar abu kulit boks dengan bahan baku kulit dari $P$. Jawa dan dari Nusa Tenggara Barat sebelum diadakan pembinaan, tidak terdapat perbedaan yang nyata $(P \leq 0,05)$, tetapi berbeda sangat nyata terhadap kadar abu kulit boks dengan bahan baku dari Nusa Tenggara Barat sesudah diadakan Pembinaan $(P \geq 0,01)$.

\section{4. $\mathrm{Kadar} \mathrm{Cr} 2 \mathrm{O} 3$}

Tabel 10 : Kadar $\mathrm{Cr} 2 \mathrm{O} 3$ kulit boks hasil proses penyamakan kulit dari Jawa, Nusa Tenggara Barat sebelum dan sesudah pembinaan (\%).

\begin{tabular}{|c|c|c|c|}
\hline No. & Jawa & $\begin{array}{c}\text { N.T.B. sebelum } \\
\text { pembinaan }\end{array}$ & $\begin{array}{c}\text { N.T.B. sesudah } \\
\text { pembinaan }\end{array}$ \\
\hline 1. & 2,672 & 3,145 & 3,020 \\
2. & 2,759 & 3,135 & 3,100 \\
3. & 3,069 & 2,870 & 3,150 \\
4. & 2,819 & 3,075 & 3,098 \\
5. & 2,631 & 3,015 & 2,899 \\
6. & 2,422 & 3,135 & 2,880 \\
\hline
\end{tabular}

Tabel 11: Analisa variasi $\mathrm{Cr} 2 \mathrm{O} 3$ kulit boks hasil proses penyamakan kuli dari Jawa, Nusa Tenggara Barat sebelum dan sesudah pembinaan.

\begin{tabular}{|l|c|c|c|c|}
\hline Sumber variasi & df & SS & MS & F \\
\hline Perlakuan & 2 & 0,380 & 0,190 & \\
Error & 15 & 0,370 & 0,020 & $9,500^{* *}$ \\
\hline
\end{tabular}

VOL VIII No. 14 Tahun 1992/1993 


\begin{tabular}{lll} 
& 2 & 3 \\
\hline SSR & 3,01 & 3,16 \\
\hline LSD & 0,18 & 0,19 \\
\hline A & C & B
\end{tabular}

Hasil uji $\mathrm{Cr} 2 \mathrm{O} 3$ dan analisa variasinya seperti terlihat pada tabel 10 dan tabel 11, dapat dilihat bahwa kulit boks dengan bahan kulit dari Nusa Tenggara Barat sebelum dan sesudah diadakan pembinaan tidak terdapat perbedaan yang nyata $(\mathrm{P} \leq 0,05)$, tetapi berbeda sangat nyata terhadap kadar abu kulit boks dengan bahan baku dari P. Jawa $(\mathrm{P} \geq 0,01)$.

2.5. $\mathrm{pH}$.

Tabel 12 : pH kulit boks hasil proses penyamakan kulit dari Jawa, Nusa Tenggara Barat sebelum dan sesudah pembinaan.

\begin{tabular}{|c|c|c|c|}
\hline No. & Jawa & $\begin{array}{c}\text { N.T.B. sebelum } \\
\text { pembinaan }\end{array}$ & $\begin{array}{c}\text { N.T.B. sesudah } \\
\text { pembinaan }\end{array}$ \\
\hline 1. & 4,000 & 3,550 & 3,500 \\
2. & 4,250 & 3,555 & 3,500 \\
3. & 3,925 & 3,490 & 3,500 \\
4. & 3,875 & 3,615 & 3,500 \\
5. & 4,000 & 3,545 & 3,500 \\
6. & 3,750 & 3,625 & 3,500 \\
\hline
\end{tabular}

Tabel 13 : Analisa variasi $\mathrm{pH}$ kulit boks hasil proses penyamakan kulit dari Jawa, Nusa Tenggara Barat sebelum dan sesudah pembinaan.

\begin{tabular}{|l|c|c|c|c|}
\hline Sumber variasi & df & SS & MS & F \\
\hline Perlakuan & 2 & 0,770 & 0,390 & \\
Error & 15 & 0,150 & 0,010 & $39,00^{* *}$ \\
\hline
\end{tabular}

Test Duncan's

\begin{tabular}{lll} 
& 2 & 3 \\
\hline SSR & 3,01 & 3,16 \\
\hline LSD & 0,12 & 0,13 \\
\hline C & B & A
\end{tabular}

Hasil uji pH kulit boks serta hasil analisa variasinya dapat dilihat pada Tabel 12 dan Tabel 13, ternyata bahwa $\mathrm{pH}$ kulit boks dengan bahan baku kulit dari Nusa Tenggara Barat sebelum dan sesudah diadakan pembinaan, tidak terdapat perbedaan yang nyata $(P \leq 0,05)$, tetapi berbeda sangat nyata terhadap kadar abu kulit boks dengan bahan baku dari $P$. Jawa $(P \geq 0,01)$.

2.6. Daya serap air selama 2 jam dan 24 jam

Tabel 14 : Daya serap air selama 2 jam kulit boks hasil proses penyamakan kulit dari Jawa, Nusa Tenggara Barat sebelum dan sesudah pembinaan.

\begin{tabular}{|c|c|c|c|}
\hline No. & Jawa & $\begin{array}{c}\text { N.T.B. sebelum } \\
\text { pembinaan }\end{array}$ & $\begin{array}{c}\text { N.T.B. sesudah } \\
\text { pembinaan }\end{array}$ \\
\hline 1. & 176,090 & 105,810 & 191,447 \\
2. & 148,610 & 118,295 & 206,731 \\
3. & 145,190 & 111,590 & 88,911 \\
4. & 147,980 & 105,950 & 114,457 \\
5. & 143,090 & 120,945 & 109,098 \\
6. & 161,120 & 128,809 & 128,809 \\
\hline
\end{tabular}

Tabel 15 : Analisa variasi daya serap air selama 2 jam kulit boks hasil proses penyamakan kulit dari Jawa, Nusa Tenggara Barat sebelum dan sesudah pembinaan.

\begin{tabular}{|l|c|c|c|c|}
\hline Sumber variasi & df & SS & MS & F \\
\hline Perlakuan & 2 & 4724,504 & 2362,252 & \\
Error & 15 & 11979,977 & 798,665 & 2,958 \\
\hline
\end{tabular}


Tabel 16 : Daya serap air selama 24 jam kulit boks hasil proses penyamakan kulit dari Jawa, Nusa Tenggara Barat sebelum dan sesudah pembinaan.

\begin{tabular}{|c|c|c|c|}
\hline No. & Jawa & $\begin{array}{c}\text { N.T.B. sebelum } \\
\text { pembinaan }\end{array}$ & $\begin{array}{c}\text { N.T.B. sesudah } \\
\text { pembinaan }\end{array}$ \\
\hline 1. & 234,350 & 143,050 & 239,236 \\
2. & 190,590 & 156,650 & 224,972 \\
3. & 157,940 & 176,770 & 118,549 \\
4. & 183,840 & 139,630 & 174,439 \\
5. & 202,250 & 173,280 & 128,771 \\
6. & 242,970 & 168,220 & 142,860 \\
\hline
\end{tabular}

Tabel 17 : Analisa variasi daya serap air selama 24 jam kulit boks hasil proses penyamakan kulit dari Jawa, Nusa Tenggara Barat sebelum dan sesudah pembinaan.

\begin{tabular}{|l|c|c|c|c|}
\hline Sumber variasi & df & SS & MS & F \\
\hline Perlakuan & 2 & 5737,727 & 2868,864 & 2,232 \\
Error & 15 & 19278,058 & 1285,204 & 2,232 \\
\hline
\end{tabular}

Hasil daya serap air selama 2 jam dan selama 24 jam untuk kulit boks serta analisa variasinya terlihat pada tabel $14,15,16$ dan tabel 17 dari tabel tersebut menunjukkan bahwa daya serap air selama 2 jam dan daya serap air selama 24 jam untuk kulit boks dengan bahan baku kulit dari $P$. Jawa dan dari Nusa Tenggara Barat sebelum dan sesudah pembinaan tidak terdapat perbedaan yang nyata $(\mathrm{P} \leq 0,05)$.

2.7. Kekuatan Tarik

Tabel 18: Kekuatan tarik kulit boks hasil proses penyamakan kulit dari Jawa, Nusa Tenggara Barat sebelum dan sesudah pembinaan.

\begin{tabular}{|c|c|c|c|}
\hline No. & Jawa & $\begin{array}{c}\text { N.T.B. sebelum } \\
\text { pembinaan }\end{array}$ & $\begin{array}{c}\text { N.T.B. sesudah } \\
\text { pembinaan }\end{array}$ \\
\hline 1. & 249,210 & 280,090 & 279,500 \\
2. & 211,110 & 314,020 & 259,360 \\
3. & 371,670 & 276,900 & 232,350 \\
4. & 175,940 & 293,120 & 208,795 \\
5. & 173,770 & 215,795 & 275,920 \\
6. & 314,250 & 253,420 & 198,845 \\
\hline
\end{tabular}

Tabel 19: Analisa variasi kekuatan tarik kulit boks hasil proses penyamakan kulit dari Jawa, Nusa Tenggara Barat sebelum dan sesudah pembinaan.

\begin{tabular}{|l|c|c|c|c|}
\hline Sumber variasi & df & SS & MS & F \\
\hline Perlakuan & 2 & 2914,567 & 1457,284 & \\
Error & 15 & 43457,936 & 2897,196 & 0,503 \\
\hline
\end{tabular}

Hasil uji dan analisa variasi kekuatan tarik kulit boks seperti terlihat pada tabel 18 dan tabel 19 , ternyata bahwa kekuatan tarik kulit boks dengan bahan baku kulit dari P. Jawa, Nusa Tenggara Barat sebelum dan sesudah diadakan pembinaan tidak terdapat perbedaan yang nyata $(\mathrm{P} \leq 0,05)$.

Tabel 20: Kekuatan regang kulit boks hasil proses penyamakan kulit dari Jawa, Nusa Tenggara Barat sebelum dan sesudah pembinaan.

\begin{tabular}{|c|c|c|c|}
\hline No. & Jawa & $\begin{array}{c}\text { N.T.B. sebelum } \\
\text { pembinaan }\end{array}$ & $\begin{array}{c}\text { N.T.B. sesudah } \\
\text { pembinaan }\end{array}$ \\
\hline 1. & 53,00 & 48,00 & 41,00 \\
2. & 63,00 & 47,00 & 41,00 \\
3. & 54,00 & 47,00 & 45,00 \\
4. & 69,00 & 45,00 & 40,00 \\
5. & 73,00 & 40,00 & 44,00 \\
6. & 56,50 & 41,50 & 39,00 \\
\hline
\end{tabular}

Tabel 21 : Analisa variasi kekuatan regang kulit boks hasil proses penyamakan kulit dari Jawa, NTB sebelum dan sesudah pembinaan.

\begin{tabular}{|l|c|c|c|c|}
\hline Sumber variasi & df & SS & MS & F \\
\hline Perlakuan & 2 & 1403,695 & 701,848 & \\
Error & 15 & 435,083 & 29,006 & 24,197 \\
\hline
\end{tabular}

Test Duncan's

\begin{tabular}{lll} 
& 2 & 3 \\
\hline SSR & 3,01 & 3,16 \\
\hline LSD & 6,619 & 6,949 \\
\hline B & C & A
\end{tabular}

VOL VIII No. 14 Tahun 1992/1993 
Hasil uji kekuatan regang kulit boks serta analisa variasinya yang terlihat pada tabel 20 dan tabel 21 , ternyata bahwa kekuatan regang kulit boks dengan bahan baku kulit dari P. Jawa, dari Nusa Tenggara Barat sebelum dan sesudah diadakan pembinaan tidak terdapat perbedaan yang nyata $(\mathrm{P} \leq 0,05)$.

2.9. Daya letup.

Tabel 22 : Daya letup kulit boks hasil proses penyamakan kulit dari Jawa, Nusa Tenggara Barat sebelum dan sesudah pembinaan.

\begin{tabular}{|c|c|c|c|}
\hline No. & Jawa & $\begin{array}{c}\text { N.T.B. sebelum } \\
\text { pembinaan }\end{array}$ & $\begin{array}{c}\text { N.T.B. sesudah } \\
\text { pembinaan }\end{array}$ \\
\hline 1. & 700 & 830 & 600 \\
2. & 700 & 850 & 700 \\
3. & 750 & 735 & 700 \\
4. & 750 & 820 & 600 \\
5. & 750 & 810 & 700 \\
6. & 600 & 870 & 700 \\
\hline
\end{tabular}

Tabel 23 : Analisa variasi daya letup kulit boks hasil proses penyamakan kulit dari Jawa, Nusa Tenggara Barat sebelum dan sesudah pembinaan. Duncan's new multiple range test.

\begin{tabular}{lll} 
& 2 & 3 \\
\hline SSR & 3,01 & 3,16 \\
\hline LSD & 64,44 & 67,66 \\
\hline C & A & B \\
\hline
\end{tabular}

Hasil Uji daya letup dan analisa variasi dari kulit boks seperti terlihat pada tabel 22 dan tabel 23 , ternyata bahwa daya letup kulit boks dengan bahan baku kulit dari P. Jawa dan dari Nusa Tenggara Barat sesudah pembinaan tidak terdapat perbedaan yang nyata $(P \leq 0,05)$, tetapi berbeda sangat nyata dengan bahan baku kulit dari Nusa Tenggara Barat sebelum diadakan pembinaan $(P \geq 0,01)$.

\section{KESIMPULAN}

Dari hasil penelitian dapat ditarik kesimpulan sebagai berikut :

1. Kulit boks dengan bahan baku kulit sapi dari P. Jawa mempunyai mutu yang cenderung lebih baik dibanding mutu kulit boks dengan bahan baku kulit sapi dari Nusa Tenggara Barat sebelum dan sesudah diadakan pembinaan.

2. Kulit boks dengan bahan baku kulit sapi dari Nusa Tenggara Barat setelah pembinaan mutunya cenderung lebih baik dibanding kulit boks dengan bahan baku kulit dari Nusa Tenggara barat diadakan pembinaan.

3. Rendahnya mutu kulit boks dengan bahan baku kulit sapi dari Nusa Tenggara Barat dikarenakan rendahnya mutu dari kulit mentahnya.

4. Cacat yang terdapat pada kulit mentah dari Nusa Tenggara Barat terutama disebabkan karena banyaknya goresan-goresan pisau, penyakit ternak, karena kurang baiknya pemeliharaan ternak, cara pengulitan dan cara pengawetan kulit.

\section{DAFTAR PUSTAKA}

1. Anonimus,

1972 "Proses Penyamakan Kulit" Balai Penelitian Kulit, Yogyakarta.

2. Anonimus,

3. Anonimus, 1965 "Syarat-syarat Mutu untuk Kulit dan Sepatu" Yayasan Dana Normalisasi Indonesia Bandung. 1979 "Mutu dan Cara Uji Kulit Boks" Badan Penelitian dan Pengembangan Industri, Departemen Perindustrian.

4. Mann. I, tural Organitation of The limited Notesis. Rome. 